\title{
PRO-COMPETITIVE REGULATION OF SELECTED INFRASTRUCTURE SECTORS IN POLAND
}

\author{
ANNA DRAB-KUROWSKA \\ University of Szczecin, Faculty of Management and Economics of Services, POLAND \\ e-mail: anna.drab@wzieu.pl
}

\begin{tabular}{l|l} 
RECEIVED & 6 November 2018 \\
ACCEPTED & 3 December 2018 \\
JEL & \\
CLASSIFICATION & L87, 197
\end{tabular}

CLASSIFICATION L87, L97

KEYWORDS postal market, regulation, post services

ABSTRACT The aim of the article is an attempt to recognize the specificity of selected infrastructure sectors in the context of pro-competitive activities. The article presents the following research hypothesis - Properly implemented pro-competitive policy will allow the increase of competition on selected markets. In reference to the assumed goal and adopted hypothesis, the following research question was posed in the article - which direction of regulation of network markets is appropriate? In an attempt to answer the question, the author of the article first looked at the situation on selected markets. Then, regulations were indicated which allowed for their gradual liberalization. The key element of the article is to present proposals for actions aimed at increasing competition in the examined markets.

\section{Introduction}

In many EU member states until recently there were, or still exist, public or private enterprises with an actual monopoly (or quasi-monopoly) that operate in certain sectors of the economy. This applies in particular to public services, such as postal services, rail and air transport, sending and transmission of energy, water supply, telecommunications, etc. It should be pointed out that the monopoly on services causes unfavourable effects for 
the dynamics of competition development (e.g. limiting cross-border competition, obstructing labour productivity convergence, limiting the use of available technologies, reducing the creation and development of new entities in the sector as well as advanced technologies).

\section{The situation on the EU market}

The beginning of the 1990s was a time of reorientation of the economies of the Central and Eastern European countries into the systems of market economies whose pillar was freedom of competition. Therefore, it was necessary to take actions aimed at liberalizing foreign trade, demonopolization of the most important sectors of the economy and privatization of the majority of state-owned enterprises. It should be emphasized, however, that the very abolition of the legal monopoly of the largest enterprises did not create competitive markets. In sectors of the economy in which the provision of services is conducted with the use of special technical infrastructure (examples are the energy and transport sector) entities that have this infrastructure have maintained the actual monopoly (dominant position) also in service markets (Skoczny, 1994, p. 78; Fornalczyk, 1997, p. 37). It should be emphasized that the European Union, aiming at liberalization of specific industries and sectors, introduces additional regulations aimed at providing recipients with services of an effective Single European Market and establishing rules of fair competition, without creating a situation where state enterprises would be forced to conduct loss-making activities. Counteracting unfavorable tendencies in practice is based on changes in the legal system and, although to a lesser extent, on the creation of programs providing financial support for projects "opening" specific markets (Skoczny, 2013, p. 13). First of all, air transport and the telecommunications sector were regulated. Then the following markets were liberalized: energy and rail transport services ${ }^{1}$ (Jurkowska, 2010, p. 43 and later). As a result of these processes, a new, Community regulatory law began to arise (Skoczny, 2002, p. 231), and in more EC member states, ${ }^{2}$ independent regulatory authorities began to be created (Szydło, 2005, pp. 289-292; Kawka, 2006, pp. 141-145).

In order to at least partially demonopolize the infrastructural sectors, the European Commission has adopted the concept of separating the infrastructure from the commercial activity of a given entity. Infrastructure, due to significant costs, may still be in the possession of the enterprise, but it is also obliged to provide other entrepreneurs with access to such infrastructure at commercial prices. Prior to the enlargement of the European Union, which took place on May 1, 2004, the following were liberalized: the telecommunications services market, both in fixed and mobile telephony, the electricity market and the aviation market. The liberalization of the market, depending on the sector to which it applies, proceeds in varying degrees and depending on the sector is at different stages. Below, the selected network markets have been analyzed.

${ }^{1}$ The first action to separate the functions of the railway infrastructure operator and the rail services provider was conducted on the basis of Directive 91/440 / EEC, but the three subsequent railway packages come from 2001, 2004 and 2007.

2 In Poland, the regulatory process and the appointment of regulatory bodies appeared - definitely under the influence of Community law - in the 1990s, i.e. during the period of association with the European Union. The first regulations and regulatory authorities were introduced in the energy and telecommunications sectors. In the Energy Law of 1997, the first - and so far only - the legal definition of regulation was published and the President of the Energy Regulatory Office (URE) was established. Then such rules were created in the sectors of transport services (air and rail transport services) and postal services. In these sectors, more or less independent regulatory bodies were also established or the economic supervision bodies existing there were granted regulatory functions and powers. 


\section{Energy market}

The energy market is by its nature a monopoly market. Due to technological and economic reasons, it is difficult in practice to create competition in a certain area of enterprises' activity, in particular, related to energy transmission (Analiza..., 2015, p. 2). Actions aimed at opening the energy market can be divided into actions aimed at separating the energy production from energy transport activities (there is a natural monopoly on the electricity transmission market), and the introduction of intermediaries as a link connecting energy producers with its recipients.

Dividing energy enterprises into smaller entities as well as introducing brokers into the market is intended to lead to lower prices in a given sector. However, research shows that there is an increase in prices on the energy market. It can be assumed that this trend results not only from higher commodity prices (because prices also record downward trends) but also from a number of other conditions. The consolidation of markets (under certain conditions) and passivity of consumers in the selection of energy suppliers can be indicated here.

The Act on Energy Law of April 10, 1997, as amended, and Directive 2009/72/EC of the European Parliament and of the Council of 13 July 2009 have the largest impact among many legal acts on the competitiveness of the energy market and on the situation of consumers in Poland. 2009/72/EC Directive concerning common rules for the internal electricity market and repealing Directive 2003/54/EC (Official Journal of the European Union L 211 of August 14, 2009), which forms the core of the so-called the third energy package, was adopted by the European Union on July 13, 2009. The main assumptions of the "electrical" directive are, among others, tightening unbundling criteria, ownership separation of energy companies (TSO, ${ }^{3} \mathrm{DSO},{ }^{4}$ trading companies), emphasizing consumer rights, the obligation to ensure so-called universal service, duration of the provider changeover procedure for a maximum of three weeks, creation of ENTSO - Agency for the Cooperation of Operators and creation of ACER - Agency for the Cooperation of Regulators (Directive 2009/72/EC). The Act - Energy Law of April 10, 1997, came into force in June 1997. It should be pointed out that although Poland was not in the structures of the European Union at that time, the law took into account many provisions covered by Directive 96/92/EC, which formed the basis of Directive 2003/54/EC, followed by the 'energy' directive (Szalbierz, Kott, 2014, pp. 371-373). This act was an impulse for introducing an organizational reform of the energy industry, consisting in separating the sectors of generation, transmission, distribution and trade. The TPA principle ${ }^{5}$ was also implemented; the Energy Regulatory Office was established, headed by the President of the Energy Regulatory Office who was independent in making decisions. Art. $23 \mathrm{sec}$. 2 of the Energy Law Act describes the obligations and competences of the President of the Energy Regulatory Office which are closely correlated with the state policy in the field of energy, i.e. economic conditions for functioning of energy companies, the concept of market functioning and requirements resulting from the obligation to adjust Polish law to European Union law (The energy Law). It should be emphasized that actions taken by an independent regulatory body are focused on fulfilling the objective set by the legislator, aimed at creating conditions for sustainable development of the country, ensuring energy security, economical and rational use of fuels and energy, development of competition, counteracting the negative effects of natural monopolies,

\footnotetext{
3 Transmission system operator.
}

${ }^{4}$ Distribution system operator.

5 Third-party Access, TPA - the principle that obligates the owner or operator to make their network infrastructure available to third parties of in order to provide services to clients. In the case of electricity, this means that the local energy distributor network can be used to deliver energy purchased from any vendor to the location indicated. 
taking into account environmental protection requirements, obligations arising from international agreements and balancing the interests of energy enterprises and recipients of fuels and energy.

The European Commission's report on competition policy for 2007 of 16 June 2008, COM (2008) indicated that the problem on the energy market is the re-monopolisation of the market. This re-monopolization was caused by the pursuit of energy companies to ensure the most favourable market position for themselves. The European Commission indicated that the entrepreneurs' pursuit to ensure a strong advantageous position on the market is connected with the use of monopolistic practices, such as prohibited agreements, foreclosure (e.g. by concluding long-term contracts or blocking access to transmission networks).

In Poland, from 1 July 2014, pursuant to the amended Energy Law from April 10, 1997 (as amended), the recipients have the option of freely choosing an energy supplier, i.e. a trading company. The purchase of energy takes place in the TPA (Third Party Access) model. ${ }^{6}$

In 2013, Distribution System Operators (DSO) ${ }^{7}$ developed a product that can increase competitiveness on the electricity sales market - a comprehensive contract for the sale and distribution of electricity (hereinafter "GUD-K"). The direction chosen by the distributors was appropriate in terms of increasing competitiveness. However, some of the conditions in it do not allow alternative energy sellers to create an offer competitive to the largest trading companies. In 2014, trading companies signed about one thousand contracts with clients based on GUD-K, which is proof of the inability to create a competitive product (WNP.PL (ICH), 2014).

The following are considered to be the greatest obstacles to the development of the competitive market in the context of deregulation processes:

a) the lack of the possibility of creating a price-competitive offer for comprehensive sales of electricity due to the transfer of all distribution fees to alternative energy sellers;

b) finding possible indications of abuse of the market position by DSOs - in comparable circumstances, offering entities from their own capital groups better conditions of cooperation than alternative energy sellers (principle of non-discrimination);

c) the use by DSO of obstructions to alternative energy sellers was identified, i.e. actions hindering the signing of contracts with customers and the subsequent provision of services.

In addition, the analysis of the possibilities of increasing competition on the electricity sales market has shown that it is necessary to eliminate a number of restrictions on the conditions of functioning of alternative trading companies (sellers of electricity). In particular, this applies to services offered on the basis of the General Distribution Agreement for a Comprehensive Contract (GUD-K), which allows for eliminating the need to pay two invoices by end customers, but does not properly regulate the relationship between participants in the wholesale market. The elimination of barriers and undertaking activities aimed at opening up to competition would constitute a clear impulse for the development of competition on this market. It should be pointed out that the implementation of the abovementioned measures would result in benefits for society, which in the context of socio-economic policy

\footnotetext{
6 This model assumes the separation of contracts for the energy seller (trading company) and energy distributor (Distribution System Operator, hereinafter "DSO"). The TPA model enables the purchase of energy at market prices. Distribution prices are regulated and approved by the Energy Regulatory Office (URE) and are not subject to trade negotiations.

${ }^{7}$ It should be noted that DSOs are not interested in providing services based on the General Distribution Agreement (which is the basis for TPA access) to their potential competitors; moreover, in many areas of cooperation there are difficulties and non-compliance with IRiESD provisions. For this reason, in most cases regulatory intervention is necessary to introduce non-discriminatory principles in cooperation between DSOs and alternative energy sellers.
} 
objectives should be considered the most important argument. In addition, the problems of this market may be suggestions or guidelines for the appropriate shaping of competition policy in the area of the Polish energy market.

\section{Transport market}

Considering the problems in the transport industry, it should be pointed out that the transport industry in Poland faced real competition from European Union companies, also in our country. The competition rules on this market are set out in Council Regulation (EC) No. 169 of February 26, 2009, on the application of competition rules to rail, road and sea transport. The most important rules of competition on the transport market in Poland include the coordination of timetables on connecting routes, the use in one mode of transport from routes that are the most rational from the point of view of exploitation, establishing uniform rules for the structure of tariffs and conditions for their use, with the reservation that these rules do not specify transport rates and conditions, organization and implementation of successive, complementary, substitute or combined transport services, as well as setting and applying flat rates and conditions for such services, including special competitive rates, standardization of equipment, transport services, vehicles and fixed installations (Szalbierz, Kott, 2014, pp. 368-370, 372). On February 2, 2010, the Council of Ministers adopted the Act on public transport under Regulation 2007/1370/EC. The new law covered road, railway, other rail, cable, terrain, sea and inland waterway transport. It should be emphasized that it clearly defined the principles of organization, functioning and financing of regular passenger transit in public transport. It should be pointed out that the proposed changes in the organization of public transport were primarily aimed at:

- separation of communication management (organization) from conducting transport,

- coordinating various public transport systems, defining clear rules for financing public transport, including providing a legal basis for financing transport from a social point of view, without taking into account the issue of profitability.

The Act explicitly emphasizes that the "public transport organizer", i.e. the local government unit or the minister of infrastructure, is responsible for organizing the regular transport of people necessary from the perspective of the general public interest. Otherwise, the transport of passengers is carried out by "commercial" carriers and functions on market terms. Transport services provided by a "commercial" carrier are performed on the basis of a confirmation of a transport declaration issued by a relevant organizer. "Public public transport operator" is a local government budget establishment or an entrepreneur authorized to provide transport services on the basis of an agreement for the provision of public transport services concluded with the organizer. The operator conducts transport operations on the basis of a contract or internal act.

The most important aspect of regulation on the transport market is ensuring the undisturbed development of this market and the competition mechanism, i.e. pro-competitive public intervention in economic activity, mainly ex-ante, but also ex-post, aimed at ensuring the proper functioning of the competition mechanism. The main goal of the regulation understood in this way is to stimulate and promote competition in the transport sector, including the railway. The tool used to carry out regulation and an integral element of the rail transport market structure in Poland, as in the case of the previously analyzed energy market, is an independent, equipped with the necessary competencies, regulator of the rail transport market, supervising the correct implementation of state policy in the field of market liberalization, stimulation and promoting the development of competition to ensure the competitiveness of the railway in relation to other modes of transport. On the basis of art. 10 section 1, 2 of the Act on railway 
transport, the position of the President of the Railway Transport Office was established, which is the central body of government administration, competent in matters of railway transport regulation.

Analysis of regulatory areas in the transport sector showed that the most important are the control mechanisms of the scope of application of preferential access rates, active market monitoring and active control of contracts, analysis of railway infrastructure management costs, and related investment costs, development of a consistent and clear procedure strictly binding fees for access to the infrastructure with costs incurred by the manager and the quality of the infrastructure provided, detailed studies on the effectiveness of particular activities, in particular the requirement to submit regulatory reports to the UTK (the Office of Rail Transport). The biggest regulatory problems of this market include the level of independence of the regulator, a dualism of UTK's roles, the institutional model of the regulator, protection of client's rights, the model of regulation of fees for access to infrastructure and the scope of regulatory powers. The effects of regulation of the railway market in Poland are competition and market stability (Szalbierz, Kott, 2014, pp. 368-370, 372). In addition, the regulations have a positive impact on this market by ensuring the stability of the market through predictable regulator policy, moreover, regulations affect the creation and enhancement of competition, expanding the rail market, business development, possibility of long-term business planning by market participants, increasing the safety of rail transport, increasing the quality of services provided by rail carriers, a drop in rail travel prices and have a positive impact on economic growth.

\section{Conclusions}

The key objective of economic regulation in the analyzed infrastructure sectors is to create conditions for arising or development of competition understood as a mechanism guaranteeing the highest possible efficiency of management leading to ensuring the highest possible level of well-being for consumers. The aim of introducing pro-competitive regulation is to replace the competition mechanism in areas where it cannot function, due to the nature and specificity of a given sector (e.g. the need to provide public services).

In addition, the aim of pro-competitive regulation is to equalize opportunities in access to key technical infrastructure. The assumption of such regulation is not only to provide access to this infrastructure (eliminating the possibility of refusal of access), but also to ensure that this access will be offered under the same conditions as it is used by the infrastructure manager or companies belonging to its capital group, i.e. the so-called non-discriminatory access to the infrastructure.

\section{References}

Analiza możliwości zwiększenia konkurencji na rynku sprzedaży energii elektrycznej (2015). Draft raportu dla Krajowej Izby Gospodarczej Elektroniki i Telekomunikacji. Audytel.

Directive 2009/72/EC concerning common rules for the internal electricity market and repealing Directive 2003/54/EC (Official Journal $L 211$ of 14.08.2009).

Fornalczyk, A. (1997). Competition Law and Policy in Poland in 1990-1995. In: T. Skoczny (ed.), Harmonisation of the Polish Competition Legislation with Competition Rules of the European Communities. Summary and Recommendations (p. 37). Warsaw: Office for Competition and Consumer Protection.

Jurkowska, A. (2010). Wspólna Polityka Transportowa w transporcie lądowym. In: A. Jurkowska, T. Skoczny (eds.), Polityki Unii Europejskiej: Polityki sektorów infrastrukturalnych. Aspekty prawne. Warszawa: Instytut Wydawniczy EuroPrawo.

Kawka, I. (2006). Telekomunikacyjne organy regulacyjne w Unii Europejskiej. Kraków: Zakamycze.

Skoczny, T. (1994). Przeciwdziałanie praktykom monopolistycznym w świetle orzecznictwa. Warszawa: Elipsa. 
Skoczny, T. (2002). Wspólnotowe prawo regulacji in statu nascendi. In: C. Mik (ed.), Prawo gospodarcze Wspólnoty Europejskiej na progu XXI wieku (pp. 213-248). Toruń: TNOiK Dom Organizatora.

Skoczny, T. (2013). Rozdział XXVI Prokonkurencyjne regulacje sektorowe. In: M. Kępiński (ed.), Prawo konkurencji. Vol. XV. Warszawa: Wydawnictwo Beck.

Szalbierz, Z., Kott, J. (2014). Regulacje instytucjonalne w sektorach infrastrukturalnych. Prace Naukowe Uniwersytetu Ekonomicznego we Wrocławiu, 372, 367-375.

Szydło, M. (2005). Regulacja sektorów infrastrukturalnych jako rodzaj funkcji państwa wobec gospodarki. Warszawa: Wydawnictwo Prawo i Praktyka Gospodarcza.

WNP.PL (ICH) (2014). Polkomtel zawarł kilkaset imów kompleksowych. Retrieved from: http://energetyka.wnp.pl/polkomtel-zawarlkilkaset-umow-kompleksowych,228147_1_0_0.html.

Cite this article aS: Drab-Kurowska, A. (2018). Pro-competitive regulation of selected infrastructure sectors in Poland. European Journal of Service Management, 4 (28/1), 87-93. DOI: 10.18276/ejsm.2018.28/1-11. 